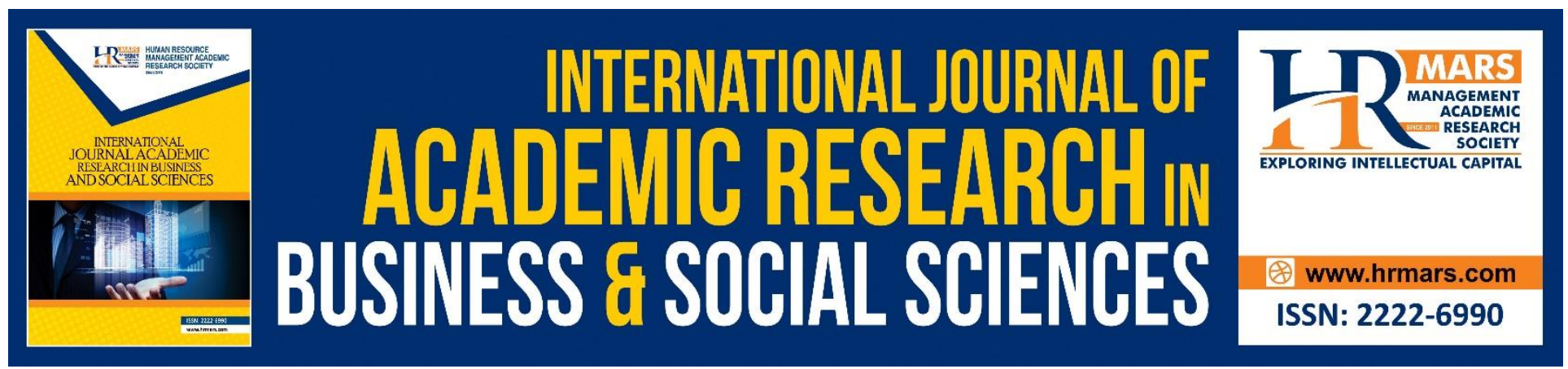

\title{
Impact of Foreign direct investment on Power production: Evidence from Nepal
}

\author{
Mohammad Rabbani
}

To Link this Article: http://dx.doi.org/10.6007/IJARBSS/v8-i11/4824

DOI: $10.6007 /$ IJARBSS/v8-i11/4824

Received: 27 Sept 2018, Revised: 19 Oct 2018, Accepted: 11 Nov 2018

Published Online: 13 Nov 2018

In-Text Citation: (Rabbani, 2018)

To Cite this Article: Rabbani, M. (2018). Impact of Foreign direct investment on Power production: Evidence from Nepal. International Journal of Academic Research in Business and Social Sciences, 8(11), 1-12.

Copyright: (C) 2018 The Author(s)

Published by Human Resource Management Academic Research Society (www.hrmars.com)

This article is published under the Creative Commons Attribution (CC BY 4.0) license. Anyone may reproduce, distribute, translate and create derivative works of this article (for both commercial and non-commercial purposes), subject to full attribution to the original publication and authors. The full terms of this license may be seen

at: http://creativecommons.org/licences/by/4.0/legalcode

Vol. 8, No. 11, 2018, Pg. 1 - 12

http://hrmars.com/index.php/pages/detail/IJARBSS

JOURNAL HOMEPAGE

Full Terms \& Conditions of access and use can be found at http://hrmars.com/index.php/pages/detail/publication-ethics 


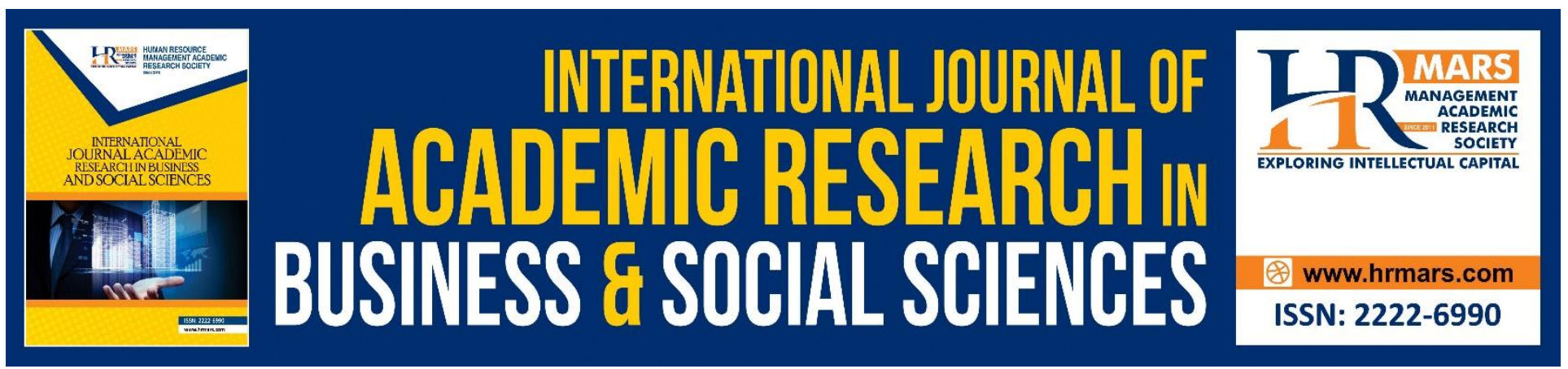

\title{
Impact of Foreign direct investment on Power production: Evidence from Nepal
}

\author{
Mohammad Rabbani \\ College of Economics and Management, Nanjing University of Aeronautics and Astronautics, 29 \\ Jiangsu Avenue, Nanjing, China
}

\begin{abstract}
Foreign direct investment can lead to strategic aims in power industry as well as economic growth. The aim of the current study is to measure the relationship between foreign direct investment and power production in Nepal while the energy consumption, economic growth, imports and exports has been used as macroeconomic variables. The results show that FDI has significant positive impact on power production. With the increase in FDI power consumption and power production will also increase. GDP also has positive impact on Power consumption. GDP is significant at 10 percent level of significance. Greater the GDP greater will be the consumption of electricity. Results of auto regressive distributive lag model in short run is found to be 0.98 which shows that $98 \%$ variations the model is good fit. The findings of short run ARDL model. While the Kurtosis and Skewness defines the shape of the distribution. It is understandable from the table 1 that the variables are only positively skewed excluding in the analysis. Kurtosis is an indicator to show the shape of distribution. And if the value greater then 3, it's called leptokurtic and the probability distribution is not normally distributed. The study provides a valuable guideline for decision and policy makers.
\end{abstract}

Keywords: FDI, Power production, ARDL, Economic growth, Nepal

\section{Introduction}

Power industry considered as strategic industry kept within a certain bounds largely by the regime. There were few participant to get (permit) countenance for laying out money in few countries. There Following advancement: rising technology, reconstituting and make a free deal of energy markets, and emerging interest on energy security. The abasement of environment and alteration of climate have set up organized opportunities for public/individual investors. Countries are trying to draw in both native and undomesticated invertors for new investment and enhance their modern overkill in replaceable and capable of being sustained technologies. Foreign direct investment (FDI) has proven to be a dependable way for many countries to approach new technologies, promote notice, income capacities, banking new investment and producing native occupation (Al-Sulaiti et al., 2010). 
INTERNATIONAL JOURNAL OF ACADEMIC RESEARCH IN BUSINESS AND SOCIAL SCIENCES Vol. 8, No. 11, Nov, 2018, E-ISSN: 2222-6990 @ 2018 HRMARS

In this way, FDI can impart to strategic aims in power industry as well while on the other hand, the research on FDI inflow in power sector have been bounded in developing countries (Production, 2007). It gained the centering on major promoting economies. Such as India or china in the last ten year's turkey has proven as remarkable economic increase and become one of the largest 20 economies in the world. Furthermore, Turkey has also an important renewable energy potential. Foreign direct investment are long term investment looking earnings by various part in the management of company in the foreign country (Nehler \& Rasmussen, 2016). FDI has become a vital source for technology transfer, economic growth and development. OECD elaborate FDI as an investment that depicts the objective of launching a permanent involvement by a resident enterprise in one economy(Direct investor) in an enterprise (Direct investment enterprise) that is resident in an economy other than that of direct investor).(Agency, 2007)

At least $10 \%$ of the voting power of enterprise must the invertors possess directly or indirectly for direct investment Some as IMF utilizes 10\% commence for average shares or voting stock as standard for macrocosm of direct investment relationship in an investment (Subic', Kljajic', \& Jeločnik, 2017). Many factors that affect the FDI decision have stressed o various theories, these factors classified under four division class of category (Habib-Mintz, 2010). Macroeconomic policies and Business/investment Environment, Standard of institutions and political constancy, Human and social capital and Country specific characteristic. Several studies concerned with the application of ARDL approach in various studies such as (Alkhath `lan and Javid, 2013), (Ahmad et al., 2016), (Khan, Ali, \& Ashfaq, 2018) and (IEA, 2015).

There are many aspects have been elaborated in literature are: overall impact on FDI inflows by statistically important evidence that FDI can take part in many facet to host economies such as give out domestic jobs, enhancing native output/yield skills and providing approach to asset (Unep \& Finance, 2009). Such as strengthening monopolistic structure in industries increasing dependency and the adverse implications of foreign control in economies, these negative impact of FDI is stipulated by some scholars (Dependency theories). By providing inductive and developing a tributary environment for investment to attracting FDI inflows countries are providing above mentioned conditions still the contribution of FDI (notably with technology transfer) in economic growth are claimed to out weight its disadvantage research on energy investment indicates that there are many hurdles for energy investment in developing economies (Lee \& Lee, 2010). The strategies that gives the progress to energy investment such as reconstituting, denationalization Fiscals inducement are considered to give rise/promote energy FDI inflows. In developing economies research/studies on FDI in the energy sector has legerity been dialed on the natural Resource investment (oil and natural gas to great extent). Relation between FDI inflows, economic. (Mohsin, Zhou, lqbal, \& Shah, 2018) measured the impact of energy security for South Asia including Nepal and (Mohsin, Rasheed, \& Saidur, 2018) assess the economic viability and production capacity of wind renewable energy in Pakistan.

In existing literature various other studies provides evidences in the favor of robustness to test the application of proposed studies such as (Dogan, 2016), (Komal \& Abbas, 2015) and in energy consumption (Nasir \& Ur Rehman, 2011). Our study empirically measured the impact of FDI on GDP, power production, imports, exports and capital formation as independent variables. We have employed quantities analysis by using panel data from 1985 to 2015 . Our study contributes by several 
ways as, we have conducted first time a quantitative investigation of FDI on GDP, power production, imports, exports and capital formation as independent variables. in Nepal. In order to ensure the FDI performance in power sector. We have used regression equation to conduct the analysis. Second, previously published studies used capital ratios but unlike others we have added several new variables as independent variables to construct a more reliable framework.

The remainder of the paper is distributed as follows. Section 2 describes the study's data collection and econometric approach. The results and discussion are presented in section 3 , while section 4 provides a conclusion and policy implication.

\section{Methodology and Data}

This study investigates the relationships among foreign direct investment and power production in Nepal while the energy consumption, economic growth, imports and exports has been used as macroeconomic variables. The disaggregated analysis of the proposed study measures the subsequent special impacts of foreign direct investment on power production economic growth energy consumption, economic growth, imports and exports. We use auto regressive lag linear functions for foreign direct investment on power production economic growth energy consumption, economic growth, imports and exports Ln-linear function to test the foreign direct investment on power production. We used the following linear Log models for analytical purposes to measure the relationship among dependent and independent variables.

$$
\begin{aligned}
& \beta_{1} \ln \mathrm{FDI}=\alpha_{0}+\beta_{1} \ln P_{P r}+\beta_{2} \ln G D P+\beta_{3} \text { lnCapital Formation }+\beta_{4} \ln \text { Exports }+ \\
& \beta_{5} \text { lnImports }+\varepsilon_{\mathrm{t}}
\end{aligned}
$$

where $P_{P r}$ indicate power production in Nepal, FDI shows foreign direct investment in Nepal Capital Formation shows the capital formation yielded by country's goods and services and $\dot{\varepsilon}$ shows the error term. For this purpose, we collected the data from 1985 to 2015 for Nepal power sector and from BP Statistics (2017), (World Bank, 2017) and Nepal statistical year book and ministries of Nepal. In this study, first we used a basic unit root test that is called augmented dicky fuller (ADF) to check the stationary of the data. The core purpose of this test was to check the stationary of the data and also to control for autocorrelation of the residue term which would not be possible in traditional dicky fuller test (Chen, 2010), (Hassler \& Wolters, 2006) and (Mbaga \& Coyle, 2003). In case the data is found to be stationary, the simple ordinary least square estimation can be applied, but in our case due to the nature of parameters used in the study we didn't pursued this strategy. Conversely, the first difference followed by second difference of the variables has been taken to transform the data from non-stationary to stationary. In the second step the optimal lag selection is performed, it is determined so as to limit the error as much as possible when employing the granger causality test and it is also useful for the bound test. Further, in the third step we used ARDL (Kripfganz \& Schneider, 2016) (autoregressive distributed lag model), this is basically used for checking the co integration for the long run relationship of variables. In the final step we used the granger causality test to check the direction of relationship. 
To measure the impact of foreign direct investment on the Nepal power production, in this study, first represent the graphical relationship of variables to get general understanding about the relationship among variables, secondly, it present the descriptive analysis, further before applying model this study apply the unit root tests on the data to check the stationary of the data so that it can be processed for further analysis (Nkoro \& Uko, 2016). Once this process has been done, this study used the ARDL approach to measure the impact of international trade on the environment, in addition this study also used granger causality test to estimate the relationship among foreign direct investment on the Nepal power production.

The ARDL bound testing method to incarcerate the long as well as short-run dynamics at disaggregate levels. This ARDL technique has several advantages and can be used if the underlying factors are integrated at level $\mathrm{I}(0)$ or first difference I(1). It offers the robustness in results despite the consequences of sample size being used in the model and it easily regulate the lags and provides the unbiased estimates having valid t-statistics for long-run model (Harris \& Sollis, 2003). Furthermore, by using the simple linear transformation, ARDL originate a dynamic unrestricted error correction model. The dynamic unrestricted error correction model join short-run dynamics and long-run equilibrium whereas it keeping long-run information intact. ARDL is an appropriate model in the existence of endogeneity and serial correlation in time series data (Pesaran, Shin and Smith, 2001). The following dynamic unrestricted error correction model were estimated to test the dynamic relationships among our variables of interest such as indicate power production in Nepal, foreign direct investment in Nepal, Capital Formation shows the capital formation yielded by country's goods and services and $\dot{\varepsilon}$ shows the error term.

$$
\begin{aligned}
& \Delta F D I_{2 t}^{R}=c_{0}+\sum_{i=1}^{p_{0}} \beta_{1} \Delta \operatorname{Pr}+\sum_{i=0}^{p_{1}} \beta_{2} \Delta G D P+\sum_{i=0}^{p_{2}} \beta_{3} \Delta \text { Exports }+\sum_{i=0}^{p_{3}} \beta_{4} \text { imports } \\
& +\sum_{i=0}^{q 1} \beta_{5} \Delta \text { CapitalFarmation }+\lambda_{1} \operatorname{Pr}_{, t-1}+\lambda_{2} G D P_{t-1}
\end{aligned}
$$

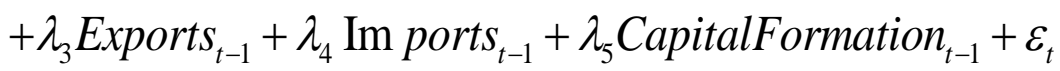

where $\Delta$ is the first difference operator while $P$, and $q$ shows the lag lengths in ARDL model, respectively. The null hypothesis of no co integration is $\left(H_{0}: \beta_{1}=\beta_{2}=\beta_{3}=\beta 4=\beta 5=0\right)$ is tested alongside its alternative hypothesis $\left(\mathrm{H}_{1}: \beta 1 \neq \beta 2 \neq \beta 3 \neq \beta 4 \neq \beta 5 \neq \neq 0\right)$, the long-run relationship is explained by the coefficients $c$ and $\beta$, and the coefficient $\lambda$ explained the short-term relationship between the dependent and independent variables being tested for proposed framework in the study.

\section{Results}

\section{Descriptive Statistics}

Table 1 indicates the descriptive statistics of the variables. Value of the Mean of the variables shows their average. The means value of POW-CON is observed of the value 340.60 , IMP has its means value of 2.76E09. GDP takes the mean value of 8.27E09 FDI means value is 40853646 . The mean value of the EXP01 is 1.49E10. The variance measures the deviation of a series from the means values of that 
INTERNATIONAL JOURNAL OF ACADEMIC RESEARCH IN BUSINESS AND SOCIAL SCIENCES Vol. 8, No. 11, Nov, 2018, E-ISSN: 2222-6990 @ 2018 HRMARS

series. The standard deviation is known as the positive square root of the variance. The standard deviation of POW-CON, IMP, GDP, FDI, EXP01are 33.50598, 2.41E+09, 6.01E+09, 45857993 and $6.37 \mathrm{E}+09$ respectively. While the Kurtosis and Skewness defines the shape of the distribution. It is obvious from the table 1 that the variables are only positively skewed excluding in the analysis. Kurtosis is an indicator to show the shape of distribution. And if the value greater then $3, \mathrm{t}$ it's called leptokurtic and the probability distribution is not normally distributed. Here three variables POWCON, GDP and EXP01 are have less than 3 kurtosis value which means these variables are normally distributed.

Table 1 Statistical Summary

\begin{tabular}{|l|c|c|c|c|c|}
\hline Variables & POW_CON & IMP & GDP & FDI & EXP01 \\
\hline Mean & 340.6008 & $2.76 \mathrm{E}+09$ & $8.27 \mathrm{E}+09$ & 40853646 & $1.49 \mathrm{E}+10$ \\
\hline Median & 341.5082 & $1.78 \mathrm{E}+09$ & $5.49 \mathrm{E}+09$ & 25000000 & $1.20 \mathrm{E}+10$ \\
\hline Maximum & 412.7245 & $8.88 \mathrm{E}+09$ & $2.14 \mathrm{E}+10$ & $2.12 \mathrm{E}+08$ & $2.45 \mathrm{E}+10$ \\
\hline Minimum & 304.1255 & $5.24 \mathrm{E}+08$ & $2.62 \mathrm{E}+09$ & 410453.0 & $4.62 \mathrm{E}+09$ \\
\hline Std. Dev. & 33.50598 & $2.41 \mathrm{E}+09$ & $6.01 \mathrm{E}+09$ & 45857993 & $6.37 \mathrm{E}+09$ \\
\hline Skewness & 0.697641 & 1.237228 & 1.062274 & 1.962918 & 0.110775 \\
\hline Kurtosis & 2.425791 & 3.278029 & 2.639388 & 7.446591 & 1.561054 \\
\hline Jarque-Bera & 2.940518 & 8.008632 & 5.998166 & 45.44646 & 2.737883 \\
\hline Probability & 0.229866 & 0.018237 & 0.049833 & 0.000000 & 0.254376 \\
\hline Observations & 31 & 31 & 31 & 31 & 31 \\
\hline
\end{tabular}

Correlation matrix is shown in table 2 below. The correlation co-efficient values are less than 0.80 which indicates that variables are not much collinear, hence there is no multicollinearity among the independent variables

Table 2 Results of Correlation Matrix

\begin{tabular}{|c|c|c|c|c|c|}
\hline Variables & POW_CON & IMP & GDP & FDI & EXP01 \\
\hline POW_CON & 1 & & & & \\
\hline IMP & 0.43 & 1 & & & \\
\hline GDP & 0.45 & 0.38 & 1 & & \\
\hline FDI & 0.69 & 0.59 & 0.68 & 1 & \\
\hline EXP01 & 0.22 & 0.33 & 0.62 & 0.61 & 1 \\
\hline
\end{tabular}

\section{Stationary of Data}

If the properties of time series properties of the data are not analyzed prior to empirical estimation, then we may have to face the problem of spurious regression. The present study this wants to analyze empirically the impact of FDI on power consumption. To avoid spurious regression that has been gained from the OLS, we have to check the unit root results. If data turned stationary we will use OLS, and if we have mixed order of integration, we may use ARDL. 
INTERNATIONAL JOURNAL OF ACADEMIC RESEARCH IN BUSINESS AND SOCIAL SCIENCES

Vol. 8, No. 11, Nov, 2018, E-ISSN: 2222-6990 @ 2018 HRMARS

\section{Econometric Issues}

This section is based on the estimation techniques description. For the Unit-root (ADF) test is applied. In practice, ADF test checks the stationary of variables. If all the variables turn I (1), then the linear combination is stationary i.e. I (0). However, if we have mixed order of integration, means I (0) or both I (1) and I (0). In this case, apply Autoregressive distributed Lag Model (ARDL) approach is applied to find the impact of FDI on trade.

\section{Auto Regressive Distributed Lag Modeling}

ARDL model can be used for a single equation. It is used for the long as well short run impacts. It provided efficient and unbiased results. This method is useful for small data Engel-Granger and Johanson is considered not to provide robust results. ARDL gives better results as compared to Johanson co-integration. There are two steps of ARDL model. First step is to estimates the long run impacts. F-statistics is used for the investigation to see the impact of lagged values. Secondly, the short and long run impact is analyzed.

\section{The Bound Test: F-Wald Test for co-integration}

The VAR model of the following form can be established as narrated by (Galvao, Montes-Rojas, \& Park, 2013) and (Zhang, Tsai, \& Chang, 2017).

$$
\begin{aligned}
& \Delta z_{t}=\mu+\alpha t+\lambda z_{t-1}+\sum_{i=1}^{p-i} \gamma_{t} \Delta y_{t-i}+\sum_{i=1}^{p-1} \gamma_{t} \Delta x_{t-i}+\varepsilon_{t} \\
& \lambda=\left[\begin{array}{c}
\lambda_{Y Y} \lambda_{Y X} \\
\lambda_{X Y} \lambda_{X X}
\end{array}\right]
\end{aligned}
$$

In this model, VECM shows the error correction mechanism, that is used to check the long run relationship for co-integration.

\section{ADF Test of Stationary}

The study applied ADF (Augmented Dickey Fuller) Test to check unit root of the following variables, which are FDI, GDP POW-CON, POW PRO INF, IMP and EXP. The variables have different order of integration i.e., some variables are stationary at level and some variables are have first order of integration, therefore we will have to apply ARDL model to analyse the empirical relationship

\begin{tabular}{|c|c|c|c|c|c|}
\hline \multirow[t]{2}{*}{ Variables } & \multicolumn{2}{|c|}{ Level } & \multicolumn{2}{|c|}{ First difference } & \\
\hline & Trend & $\begin{array}{c}\text { Trend \& } \\
\text { Inter }\end{array}$ & Trend & $\begin{array}{c}\text { Trend \& } \\
\text { Inter }\end{array}$ & \\
\hline FDI & -2.72 & -4.24 & -- & -- & $I(0)$ \\
\hline GDP & 2.75 & -0.33 & -3.48 & -4.61 & $\mathrm{I}(1)$ \\
\hline Pow_Con & 0.61 & -2.22 & -6.83 & -7.49 & $\mathrm{I}(1)$ \\
\hline Pow_Pro & -1.38 & -3.77 & -- & -- & $I(0)$ \\
\hline Imp & 4.47 & 1.12 & -3.26 & -5.07 & $\mathrm{I}(1)$ \\
\hline Exp & -1.22 & -1.96 & -5.59 & -5.54 & $\mathrm{I}(1)$ \\
\hline
\end{tabular}

Table 3 
INTERNATIONAL JOURNAL OF ACADEMIC RESEARCH IN BUSINESS AND SOCIAL SCIENCES

Vol. 8, No. 11, Nov, 2018, E-ISSN: 2222-6990 (C) 2018 HRMARS

The results of the bound test are shown in table below, If the statistic lies between the bounds, the test is inconclusive. If it is above the upper bound, the null hypothesis of no level effect is rejected. If it is below the lower bound, the null hypothesis of no level effect can't be rejected. The critical value bounds are computed by stochastic simulations using 20000 replications.

$\beta_{1} \ln \mathrm{FDI}=\alpha_{0}+\beta_{1} \ln P_{P r}+\beta_{2} \ln G D P+\beta_{3} \ln$ Capital Formation $+\beta_{4} \ln$ Exports +

$\beta_{5}$ lnImports $+\varepsilon_{\mathrm{t}}$

Table 4 Results of Bound Test

\begin{tabular}{|c|c|c|c|c|}
\hline \multicolumn{2}{|c|}{ Testing for existence of a level relationship among the variables in the ARDL model } \\
\hline F-statistic & $\begin{array}{l}\text { 95\% Lower } \\
\text { Bound }\end{array}$ & $\begin{array}{l}\text { 95\% Upper } \\
\text { Bound }\end{array}$ & $\begin{array}{l}\mathbf{9 0 \%} \text { Lower } \\
\text { Bound }\end{array}$ & $\begin{array}{l}\mathbf{9 0 \%} \text { Upper } \\
\text { Bound }\end{array}$ \\
\hline 5.9474 & 4.1977 & 5.5082 & 3.4682 & 4.6455 \\
\hline W-statistic & $\begin{array}{l}95 \% \text { Lower } \\
\text { Bound }\end{array}$ & $\begin{array}{l}\text { 95\% Upper } \\
\text { Bound }\end{array}$ & $\begin{array}{l}90 \% \text { Lower } \\
\text { Bound }\end{array}$ & $\begin{array}{l}90 \% \text { Upper } \\
\text { Bound }\end{array}$ \\
\hline $.3111 \mathrm{E}-3$ & 20.9886 & 27.5409 & 17.3408 & 23.2276 \\
\hline
\end{tabular}

Table 5 Estimated Long Run Coefficients using the ARDL Approach

ARDL $(1,1,0,1,0)$ selected based on Schwarz Bayesian Criterion

Dependent variable is POW_CON

30 observations used for estimation from 1986 to 2015

\begin{tabular}{|c|c|c|c|c|}
\hline Regressor & Coefficient & Standard Error & T-Ratio & Prob \\
\hline FDI & $.1628^{* *}$ & .0852 & 1.9101 & .070 \\
\hline GDP & $.6931^{* * *}$ & .2606 & 2.6595 & .008 \\
\hline EXP_YEAR & $.1996^{*}$ & .1197 & 1.6680 & .110 \\
\hline IMP_YEAR & $.494^{* * *}$ & .0628 & 7.8601 & .000 \\
\hline Trend & $2.987^{* * *}$ & .83326 & 3.5858 & .002 \\
\hline C & $295.251^{* * *}$ & 5.8824 & 50.1921 & .000 \\
\hline
\end{tabular}

FDI has significant positive impact on Power consumption. The variable is significant at 5 percent level. With the increase in FDI power consumption will also increase. GDP also has positive impact on Power consumption. GDP is significant at 10 percent level of significance. Greater the GDP greater will be the consumption of electricity. The variables IMP-year, EXP-year and trend also have positive association with power consumption and are significant at 1 percent, 10 percent and 10 percent respectively. 
INTERNATIONAL JOURNAL OF ACADEMIC RESEARCH IN BUSINESS AND SOCIAL SCIENCES

Vol. 8, No. 11, Nov, 2018, E-ISSN: 2222-6990 @ 2018 HRMARS

Table 6 Results of ARDL for short run

Autoregressive Distributed Lag Estimates

Dependent variable is POW_CON

30 observations used for estimation from 1986 to 2015

$\operatorname{ARDL}(1,1,0,1,0)$ selected based on Schwarz Bayesian Criterion

\begin{tabular}{|c|c|c|c|c|c|}
\hline Regressors & \multicolumn{2}{|c|}{ Coefficient } & $\begin{array}{l}\text { Standard } \\
\text { Error }\end{array}$ & T-Ratio & Prob. \\
\hline POW_CON(-1) & \multicolumn{2}{|c|}{$.40500 * * *$} & .14088 & 2.8749 & {$[.009]$} \\
\hline FDI & \multicolumn{2}{|c|}{.2392} & .3455 & .69247 & {$[.496]$} \\
\hline FDI(-1) & \multicolumn{2}{|c|}{$.7295 *$} & .3942 & 1.8506 & {$[.078]$} \\
\hline GDP & \multicolumn{2}{|c|}{$.4124 \mathrm{E}$} & .1575 & .26183 & {$[.796]$} \\
\hline EXP_YEAR & \multicolumn{2}{|c|}{$.2398 * * *$} & .7385 & 3.2468 & {$[.004]$} \\
\hline EXP_YEAR(-1) & \multicolumn{2}{|c|}{$-.3586 * * *$} & .7808 & -4.5923 & {$[.000]$} \\
\hline IMP_YEAR & \multicolumn{2}{|c|}{.2941} & .3629 & .81041 & {$[.427]$} \\
\hline Trend & \multicolumn{2}{|c|}{$1.7778 * * *$} & .5511 & 3.2261 & {$[.004]$} \\
\hline $\mathrm{C}$ & \multicolumn{2}{|c|}{$175.6739 * * *$} & 40.4465 & \multirow[t]{2}{*}{4.3434} & {$[.000]$} \\
\hline \multicolumn{2}{|l|}{ R-Squared } & .98170 & R-Bar-Squared & & .97473 \\
\hline \multicolumn{2}{|c|}{ S.E. of Regression } & 5.3093 & \multicolumn{2}{|c|}{ F-Stat. $\quad F(8,21)$} & $140.8133[.000]$ \\
\hline \multicolumn{2}{|c|}{$\begin{array}{l}\text { Mean of Dependent } \\
\text { Variable }\end{array}$} & 341.7979 & \multicolumn{2}{|c|}{ S.D. of Dependent Variable } & 33.3976 \\
\hline \multicolumn{2}{|c|}{ Residual Sum of Squares } & 591.9613 & \multicolumn{2}{|c|}{ Equation Log-likelihood } & -87.3018 \\
\hline \multicolumn{2}{|c|}{ Akaike Info. Criterion } & -96.3018 & Schwarz Bay & riterion & -102.6072 \\
\hline DW-statistic & & 2.5744 & Durbin's h-s & & $-2.1732[.013]$ \\
\hline
\end{tabular}

Results of ARDL model in short run are reported in table 6. R Squared value is found to be 0.98 which indicates that 98 percent variations in the dependent variable have been explained by the independent variables. The model is good fit. The value of DW statistics is 2.5 which indicate that there is no auto correlation among the variables. Probability $F$ statistics value is 0.00 which shows that overall model is significant at 1 percent level of significance. The findings of short run ARDL model indicate that exchange all the variables have positive association with power consumption except the variable of Imports. FDI has insignificant impact on power consumption however FDI with lag one has significant impact on power consumption in short run.

\section{Conclusion}

FDI has significant positive impact on Power consumption. The variable is significant at 5 percent level. With the increase in FDI power consumption will also increase. GDP also has positive impact on Power consumption. GDP is significant at 10 percent level of significance. Greater the GDP greater will be the consumption of electricity. The variables IMP-year, EXP-year and trend also have positive association with power consumption and are significant at 1 percent, 10 percent and 10 percent respectively. Results of ARDL model in short run and the $R$ Square value is found to be 0.98 which shows that $98 \%$ variations in the dependent variable have been explained by the independent variables. The model is good fit while the value of DW statistics is 2.5 shows that there is no auto 
correlation among the variables. Probability $F$ statistics value is 0.00 which shows that overall model is significant at 1 percent level of significance. The findings of short run ARDL model. While the Kurtosis and Skewness defines the shape of the distribution. It is understandable from the table 1 that the variables are only positively skewed excluding in the analysis. Kurtosis is an indicator to show the shape of distribution. And if the value greater then $3, \mathrm{t}$ it's called leptokurtic and the probability distribution is not normally distributed. Here three variables POW-CON, GDP and EXP01 are have less than 3 kurtosis value which means these variables are normally distributed.

We recommend there should be conducted an empirical study to increase the power production process and suggest a policy framework in order to reduce the power shortfall.

Foreign direct investment, GDP, Capital requirement, exports and imports should be studied with a more advance mathematical model in order to ensure more robust results. Finally, assessing the impact in view of greater view should be conducted and we recommend the sensitivity analysis for future research. As for methodology is concerned we employed logistic regression and various other variables (GDP, power production, imports, exports and capital formation as an independent variables) to measure the relationship between FDI and power production in Nepal. A new operation research model and an innovative econometric model is recommended for future research in order to ensure the more reliable results.

\section{References}

Agency, I. E. (2007). Climate Policy Uncertainty and Investment Risk. Energy, 17(7), 144. https://doi.org/http://dx.doi.org/10.1016/j.bbr.2011.03.031

Ahmad, A., Zhao, Y., Shahbaz, M., Bano, S., Zhang, Z., Wang, S., \& Liu, Y. (2016). Carbon emissions, energy consumption and economic growth: An aggregate and disaggregate analysis of the Indian economy. Energy Policy, 96, 131-143. https://doi.org/10.1016/j.enpol.2016.05.032

Al-Sulaiti, K. I., Baker, M. J., Bryman, A., Baker, M. J., Ballington, L., Bilkey, W. J., ... Saunders, M. N. K. K. (2010). Research Methods for Business Students. International Marketing Review, 14(2), 656. https://doi.org/10.4135/9781412986182

Alkhathlan, K., \& Javid, M. (2013). Energy consumption, carbon emissions and economic growth in saudi arabia: An aggregate and disaggregate analysis. Energy Policy, 62, 1525-1532. https://doi.org/10.1016/j.enpol.2013.07.068

BP Statistics. (2017). BP Statistics.

Chen, Y. (2010). Autoregressive Distributed Lag ( ADL ) Model. Interpretation A Journal Of Bible And Theology, 1-3.

Dogan, E. (2016). Analyzing the linkage between renewable and non-renewable energy consumption and economic growth by considering structural break in time-series data. Renewable Energy, 99, 1126-1136. https://doi.org/10.1016/j.renene.2016.07.078

Galvao, A. F., Montes-Rojas, G., \& Park, S. Y. (2013). Quantile Autoregressive Distributed Lag Model with an Application to House Price Returns. Oxford Bulletin of Economics and Statistics, 75(2), 307-321. https://doi.org/10.1111/j.1468-0084.2011.00683.x

Habib-Mintz, N. (2010). Biofuel investment in Tanzania: Omissions in implementation. Energy Policy, 38(8), 3985-3997. https://doi.org/10.1016/j.enpol.2010.03.023

Harris, R., \& Sollis, R. (2003). Applied Time Series Modelling and Forecasting. Book. 
INTERNATIONAL JOURNAL OF ACADEMIC RESEARCH IN BUSINESS AND SOCIAL SCIENCES

Vol. 8, No. 11, Nov, 2018, E-ISSN: 2222-6990 @ 2018 HRMARS

Hassler, U., \& Wolters, J. (2006). Autoregressive distributed lag models and cointegration. In Modern Econometric Analysis: Surveys on Recent Developments (pp. 57-72). https://doi.org/10.1007/3-540-32693-6_5

IEA. (2015). Energy and Climate Change. World Energy Outlook Special Report, 1-200. https://doi.org/10.1038/479267b

Khan, M. T. I., Ali, Q., \& Ashfaq, M. (2018). The nexus between greenhouse gas emission, electricity production, renewable energy and agriculture in Pakistan. Renewable Energy, 118, 437-451. https://doi.org/10.1016/j.renene.2017.11.043

Komal, R., \& Abbas, F. (2015). Linking financial development, economic growth and energy consumption in Pakistan. Renewable and Sustainable Energy Reviews, 44, 211-220. https://doi.org/10.1016/j.rser.2014.12.015

Kripfganz, S., \& Schneider, D. C. (2016). ardl : Stata module to estimate autoregressive distributed lag models. Retrieved from http://www.stata.com/meeting/chicago16/slides/chicago16_kripfganz.pdf

Lee, I., \& Lee, B. C. (2010). An investment evaluation of supply chain RFID technologies: A normative modeling approach. International Journal of Production Economics, 125(2), 313-323. https://doi.org/10.1016/j.ijpe.2010.02.006

Mbaga, M., \& Coyle, B. T. (2003). Beef Supply Response Under Uncertainty: An Autoregressive Distributed Lag Model. Journal of Agricultural and Resource Economics, 28(3), 519-539.

Mohsin, M., Rasheed, A. K., \& Saidur, R. (2018). Economic viability and production capacity of wind generated renewable hydrogen. International Journal of Hydrogen Energy. https://doi.org/10.1016/j.ijhydene.2017.12.113

Mohsin, M., Zhou, P., Iqbal, N., \& Shah, S. A. A. (2018). Assessing oil supply security of South Asia. Energy, 155, 438-447. https://doi.org/10.1016/J.ENERGY.2018.04.116

Nasir, M., \& Ur Rehman, F. (2011). Environmental Kuznets Curve for carbon emissions in Pakistan: An empirical investigation. Energy Policy, 39(3), 1857-1864. https://doi.org/https://doi.org/10.1016/j.enpol.2011.01.025

Nehler, T., \& Rasmussen, J. (2016). How do firms consider non-energy benefits? Empirical findings on energy-efficiency investments in Swedish industry. Journal of Cleaner Production, 113, 472482. https://doi.org/10.1016/j.jclepro.2015.11.070

Nkoro, E., \& Uko, A. K. (2016). Autoregressive Distributed Lag (ARDL) cointegration technique: application and interpretation. Journal of Statistical and Econometric Methods, 5(4), 63-91. https://doi.org/10.1002/jae.616

Pesaran, M. H., Shin, Y., \& Smith, R. J. (2001). Bounds testing approaches to the analysis of level relationships. Journal of Applied Econometrics, 16(3), 289-326. https://doi.org/10.1002/jae.616

Production, H. (2007). Hydrogen Production \& Distribution. IEA Energy Technology Essentials, (1), 3-6.

Subic', J., Kljajic', N., \& Jeločnik, M. (2017). Renewable energy use in raspberry production. Economics of Agriculture, 64(2), 821-843. Retrieved from https://hau.idm.oclc.org/login?url=http://search.ebscohost.com/login.aspx?direct=true \&db=la h\&AN=20173224036\&site=ehost- 
INTERNATIONAL JOURNAL OF ACADEMIC RESEARCH IN BUSINESS AND SOCIAL SCIENCES

Vol. 8, No. 11, Nov, 2018, E-ISSN: 2222-6990 @ 2018 HRMARS

live\&scope=site\%0Ahttp://www.cabi.org/cabdirect/showpdf.aspx?PAN=http://www.cabi.org/ cabdirect/showpdf.aspx?PAN=20173224036\%0Ahttp://bsaae.b

Unep, \& Finance, N. E. (2009). Global trends in sustainable energy investment 2009: Analysis of trends and issues in the financing of renewable energy and energy efficiency. Energy, 40.

Retrieved from

http://sefi.unep.org/fileadmin/media/sefi/docs/publications/Global_Trends_2009_July_09_ ISBN.pdf

World Bank. (2017). World Development Indicators.

Zhang, Z., Tsai, S. L., \& Chang, T. (2017). New Evidence of Interest Rate Pass-through in Taiwan: A Nonlinear Autoregressive Distributed Lag Model. Global Economic Review, 46(2), 129-142. https://doi.org/10.1080/1226508X.2017.1278710 